\title{
Risk factors for high bulk milk somatic cell counts in dairy herds from Campos das Vertentes region, Minas Gerais State, Brazil: a case-control study ${ }^{1}$
}

\author{
Geraldo M. Costa ${ }^{2 *}$ (D), Alan A. Mesquita ${ }^{3}$ (D), Christiane M.B.M. Rocha2 \\ Fabio R.P. Bruhn ${ }^{4}$, Rafaella S. Andrade ${ }^{2}$, Dircéia A.C. Custódioº ${ }^{2}$ Mirian S. Braz ${ }^{2}$ \\ and Sandra M. Pinto ${ }^{5}$
}

\begin{abstract}
Costa G.M., Mesquita A.A., Rocha C.M.B.M., Bruhn F.R.P., Andrade R.S., Custódio D.A.C., Braz M.S. \& Pinto S.M. 2019. Risk factors for high bulk milk somatic cell counts in dairy herds from Campos das Vertentes region, Minas Gerais State, Brazil: a case-control study. Pesquisa Veterinária Brasileira 39(8):606-613. Departamento de Medicina Veterinária, Universidade Federal de Lavras, Campus Universitário, Cx. Postal 3037, Lavras, MG 37200-000, Brazil. E-mail: gmcosta@ufla.br

High bulk milk somatic cell counts (BMSCC) are indicative of failures related to the control of mastitis in the herd, which compromises the quality of the milk and generates great losses for the producers and for the industry. A case-control study was carried out in dairy herds in the Campos das Vertentes region, Minas Gerais State, Brazil, in order to contribute to the knowledge of the risk factors involved with elevated BMSCC. The study involved 46 dairy herds, of which 30 were considered cases (BMSCC $\geq 700,000$ cells $/ \mathrm{mL}$ of milk) and 16 control farms (BMSCC $\leq 200,000$ cells/mL of milk). Sixteen qualitative variables and four quantitative variables were analyzed. The results showed that the risk factors for BMSCC $\geq 700,000$ cells/ $\mathrm{mL}$ were the presence of Staphylococcus aureus and Streptococcus agalactiae pathogens in bulk milk, non-use of pre and post-dipping, non-use of disposable paper towel for drying of mammary glands, non-monitoring of mastitis in the herd by means of California Mastitis Test (CMT) or individual somatic cell counts (SCC), non-implementation of the milking line and therapy of dry cows and failures in hygiene of teats and udders before milking. Moderate correlations were also observed between the elevation of BMSCC and counts of $S$. aureus and BMSCC and counts $S$. agalactiae in bulk milk, and a moderate correlation between S. aureus and S. agalactiae counts in bulk milk. Failures with regard to the maintenance and use of milking equipment, including manual pressure application in milking assemblies, unregulated milking vacuum pressure, and vacuum loss during milking, and maintenance failures of the milking machine and bulk milk tank were also pointed out as important risk factors of BMSCC elevation. The results of this study provided subsidies for the elaboration of more effective programs for mastitis control and improvement of raw milk quality, reducing the losses caused by the disease to producers and industry.
\end{abstract}

INDEX TERMS: Risk factors, milk, somatic cell, dairy herds, Minas Gerais, Brazil, mastitis, case-control study, cattle.

\footnotetext{
${ }^{1}$ Received on December 9, 2018.

Accepted for publication on February 21, 2019.

${ }^{2}$ Departamento de Medicina Veterinária, Universidade Federal de Lavras (UFLA), Campus Universitário, Cx. Postal 3037, Lavras, MG 37200-000, Brazil. *Corresponding author: gmcosta@ufla.br

${ }^{3}$ Departamento de Zootecnia, Universidade Federal de Lavras (UFLA), Campus Universitário, Cx. Postal 3037, Lavras, MG 37200-000.

${ }^{4}$ Faculdade de Veterinária, Universidade Federal de Pelotas (UFPel), Cx. Postal 354, Campus Universitário s/n, Capão do Leão, RS 96010-900, Brazil.

${ }^{5}$ Departamento de Ciências dos Alimentos, Universidade Federal de Lavras (UFLA), Campus Universitário, Cx. Postal 3037, Lavras, MG 37200-000.
}

RESUMO.- [Fatores de risco para contagens elevadas de células somáticas no leite de tanque em rebanhos de bovinos da região de Campos das Vertentes, Minas Gerais, Brasil: um estudo de caso-controle.] Altas contagens de células somáticas no leite do tanque (CCSt) são indicativas de falhas relacionadas com o controle da mastite no rebanho, o que compromete a qualidade do leite e gera grandes perdas para os produtores e para a indústria. Visando identificar os fatores de risco envolvidos com a CCSt elevada, foi realizado 
um estudo de caso-controle em rebanhos bovinos leiteiros da região de Campos das Vertentes, em Minas Gerais. 0 estudo envolveu 46 propriedades, das quais 30 foram consideradas casos (CCSt $\geq 700.000$ cels $/ \mathrm{mL}$ de leite) e 16 propriedades controles (CCSt $\leq 200.000$ cels/mL de leite). Foram analisadas 16 variáveis qualitativas e quatro variáveis quantitativas. Os resultados demonstraram que os fatores de risco para valores de CCSt $\geq 700.000$ cels/mL de leite foram a presença dos patógenos Staphylococcus aureus e Streptococcus agalactiae, não utilização do pré e de pós-dipping, não utilização de papel toalha descartável para a secagem dos tetos, não monitoramento da mastite por meio do California Mastitis Test (CMT) ou CCS individual, não implementação da linha de ordenha e da terapia de vacas secas e falhas na higiene de tetos e de úbere antes da ordenha. Também se observaram correlações moderadas entre a CCSt e as contagens de $S$. aureus e entre CCSt e as contagens de $S$. agalactiae, e correlação moderada entre as contagens de $S$. aureus e de $S$. agalactiae no leite do tanque. Falhas com relação à manutenção e utilização dos equipamentos de ordenha, aplicação de pressão manual nos conjuntos da ordenha, pressão de vácuo da ordenha desregulada, perda de vácuo durante a ordenha e falhas de manutenção da ordenhadeira e do tanque de expansão foram também apontadas como fatores de risco para elevação da CCSt. Os resultados deste estudo possibilitaram identificar fatores de risco importantes para contagens elevadas de CCSt que poderão fornecer subsídios para a elaboração de programas de controle mais efetivos para a mastite e para a melhoria da qualidade do leite, mitigando o impacto que a doença causa para os produtores e para a indústria.

TERMOS DE INDEXAÇÃO: Fatores de risco, contagem de células, células somáticas, leite de tanque, bovinos, Minas Gerais, Brasil, mastite, estudo caso-controle.

\section{INTRODUCTION}

In Brazil, the consumption of milk and dairy products has showed a tendency of growing, as seen by the $42.6 \%$ increase in the annual per capita acquisition of these products from 2000 to 2015 , totaling 174 liters of dairy products/year per inhabitant (IBGE 2017).The elevated nutritional value of milk, due to its proteins, fats, carbohydrates, vitamins and mineral salts has contributed to this increased of dairy consumption (Ribeiro 2008). Although, the consumers are increasingly worried about the quality, functionality and risks associated to food products (Carvalho 2010).

This increased concern with quality led to changes in legislation, aiming to adequate the milk production to the consumer market requirements. Thus, the Normative Instructions IN51 (Brasil 2002), IN62 (Brasil 2011) and IN7 (Brasil 2016) were created to regulate the production and quality parameters of the milk produced in Brazil. The adequation to legislation led to changes in the payment of milk acquired by dairy producers, introducing bonus for products with higher percentage of nutritional constituents and higher quality indexes, indicated mainly by reduction in the total bacterial count (TBC) and bulk-milk somatic cell count (BMSCC) (Guerreiro et al. 2005).

The milk from herds with high values of TBC and BMSCC results in worse quality dairy products (Politis \& Ng-Kwai-Hang 1988). Changes in milk composition due to breast infections reduce the products nutritional values and raise processing problems, which can lead to products out of the desired quality standards. High values of BMSCC are also directly related to lower yield of the dairy production (Santos \& Fonseca 2007, Lopes et al. 2012). In addition, increased BMSCC due to intramammary infections (IMI) caused by certain mastitis pathogens, such as Streptococcus agalactiae, reduces the shelf life of milk and its derivates (Barbano et al. 2006).

Among the milk quality parameters, BMSCC is the main index of mammary gland health of the cows of the herd. In the presence of bacterial infection and inflammatory process, the somatic cell count (SCC) can reach high values due to the increase in leukocytes that migrate to the mammary glands to struggle the infectious agents (Dong et al. 2012). Thus, periodic BMSCC evaluations can determine the average frequency of mastitis in the herd (Machado et al. 2000). According to the National Mastitis Council (NMC 1996), the prevalence of mastitis in the herd is directly related to the BMSCC. Counts of 200,000 cells/mL of milk indicate that approximately $6 \%$ of the herd's mammary quarters are infected and, when these counts reach 1,500,000 cells/mL of milk, it indicates that approximately $48 \%$ of the herd's mammary quarters may have mastitis.

Mastitis is a multifactorial disease, thus characteristics specific to the animals and also of the environment where the milk is produced and handled are considered important risk factors to IMI and milk quality (Omore et al. 1996). Among the first we can cite the number of parities, stage of lactation and individual production (Souza 2005). Risk factors related to the milking handling, such as manual or mechanical milking and lack of antisepsis of the teats before and after milking are associated with the occurrence of IMI and high values of BMSCC (Brito et al. 1998).

According to Cavazos (2003), inadequate functioning of milking equipment, lack of training and low motivation of the milkers are also associated with increased BMSCC. Periodic microbiological tests are also important to control and prevent mastitis and consequently reduce BMSCC; they allow to evaluate the present pathogens and monitor the index of infections in the herd, helping the adoption of control measures more adequate according to the agents present in the herd (NMC 2000).

Even though several contagious and environmental pathogens can be involved in causing mastitis, Staphylococcus aureus, Streptococcus uberis, S. agalactiae, S. dysgalactiae and Escherichia coli are the most common (Ranjan et al. 2006) and are usually associated with more severe mastitis (Reyher et al. 2012). According to Keefe (2012), S. agalactiae and S. aureus are considered bovine mastitis primary pathogens due to its impact in the production and quality of milk, especially in BMSCC. The main propagation method of these pathogenic agents within the herd is through infected cows, which serve as reservoirs. According to Brito et al. (1999), among these bacteria, named primary pathogens, $S$. aureus e $S$. agalactiae are the most commonly isolated microorganisms in cases of mastitis, being responsible for approximately $26 \%$ of the IMI in herds of Minas Gerais state.

Due to mastitis multifactorial aspect, the study of its risk factors is of great importance, considering that the intervening factors of this disease are dynamic and vary among herds. One of the alternatives for this kind of study is the case control 
study, which includes epidemiological evaluations that are observational, longitudinal, retrospective and analytical. This type of study aims to create hypotheses for future investigations of diseases with risk factors that are not completely known, or for confirmatory studies to test pre-established hypotheses through the investigation of suspected factors (Rêgo 2010).

Despite several studies focused on the BMSCC aspects and its impact in the milk's quality, and studies related to mastitis risk factors in Brazilian bovine herds (Vilela \& Nogueira 2010, Costa et al. 2012, Mendonça et al. 2016), there is still a lack of recent studies on the risk factors for the BMSCC increase. Such studies can help in the adoption of public policies for mastitis control and improvement of milk's quality, resulting in higher productivity for the producers, higher yield for the dairy industry e higher security for the consumer. Thus, the objective of this case control was to identify the main risk factors related to increase of the BMSCC, aiming to contribute to the knowledge of mastitis risk factors and the increase of milk quality in bovine dairy herds from the region of Campos das Vertentes, Minas Gerais, state.

\section{MATERIALS AND METHODS}

We performed a case control study to test the association of biological variables, sanitary handling and milking with the herds BMSCC. The BMSCC was considered the dependent variable. Thus, to perform the study, we randomly selected 46 milk producing properties located in the dairy farming region of Campos das Vertentes, in Minas Gerais state. The properties analyzed had approximately 1600 total animals (FAEMG 2006), 30 of them were considered cases and the remaining properties (16) were considered controls. The farms selected as cases presented BMSCC $\geq 700,000$ cells $/ \mathrm{mL}$ of milk, values that indicate a high prevalence of mastitis in the herd. The properties considered controls presented BMSCC $\leq 200,000$ cells $/ \mathrm{mL}$ of milk, indicating low prevalence of mastitis and superior milk quality.

We gathered information on the risk factors related to high scores of BMSCC, i.e., the biological variables, sanitary handling and milking. We also considered as possible risk factors the presence or absence of the pathogens Staphylococcus aureus and Streptococcus agalactiae in the milk samples obtained from the bulk milk tanks of these properties.

We used the results of the three last BMSCC analyses of each property and the milk quality data provided by the dairy, obtained with the laboratories of the Brazilian Network of Milk Quality.

The independent variables were obtained by using a questionnaire and in loco observation through technical visits to the properties. Data were obtained by a trained team composed of assistant technicians of the dairy that receive the milk from the studied properties. The criteria for deciding the tested variables included those that offered biological explanation for the increased BMSCC.

The following independent variables were raised in the interview: use of Tamis test, ; pre and post dipping; drying of the teats with disposable paper towel after the pre-dipping; monthly California mastitis test (CMT) or SCC evaluations; use of milking line for animals identified with clinical and subclinical mastitis; dry cow therapy and treatment of clinical cases. In addition, we evaluated whether the properties had cows with hyperkeratosis; whether the body score of all animals indicated good nutrition of the herd; and whether there were animals with thermal stress in any moment of the milking.

Related to the milking, we evaluated: the teats and udder hygiene before milking; the use of manual pressure during milking; entry of air in the milk sets during milking; the vacuum pressure of the milking machine according to the manufacturer's indication; periodic maintenance and adjustments of the milking machines and bulk milk tanks; and the automated hygiene of the milking machine and bulk milk tanks. We also verified if the milking period was superior to 2 hours and 30 minutes after the animals' arrival at the waiting room, and if the milking routine was calm, without the presence of dogs or other stress factors to the animals.

The presence of $S$. aureus and/or $S$. agalactiae was evaluated in samples of approximately $40 \mathrm{~mL}$ of milk, collected directly from the bulk milk tank in the studied properties; the samples were submitted to microbiological analysis, using selective media for the identification and quantification of these pathogens. For that, we performed serial dilutions of milk in sterile saline, which were plated in the selective culture media. The count of $S$. aureus was performed with Agar Baird-Parker (Oxoid ${ }^{\circledR}$ ), according to the manufacturer's instructions. The count of $S$. agalactiae was performed with modified Agar Edwards (Oxoid ${ }^{\circledR}$ ) enriched with $5 \%$ bovine blood, according to the manufacturer's instructions. In the plates showing growth of colonies suggestive of the agents of interest, we randomly selected five colonies that were submitted to confirmatory tests, according to Oliver et al. (2004a).

We performed descriptive analyses of all variables raised. For quantitative variables, we performed the data Kolmogorov-Smirnov normality test. We used non-parametric tests, including the Spearman coefficient, to test the correlations, and the Mann-Whitney test for comparison of rated means, considering $5 \%$ significance level.

The associations were tested with univariate analyses using the Pearson's chi-square test with 5\% significance level. In a following step, we calculated the Odds Ratio with a 95\% confidence interval.

The correlation tests between the BMSCC quantitative variables, daily milk production, $S$. aureus count and $S$. agalactiae count were performed using the non-parametric Spearman's test, with $1 \%$ and $5 \%$ significance levels.

The statistical analyses were performed using the Statistical Package for the Social Sciences (SPSS, Chicago, USA) version 20.0 for Windows.

\section{RESULTS AND DISCUSSION}

Among the case properties (BMSCC $\geq 700,000$ cells $/ \mathrm{mL}$ ), $80 \%$ presented the pathogen Streptococcus agalactiae and 76.6\% presented Staphylococcus aureus, while in the control properties (BMSCC $\leq 200,000$ cells $/ \mathrm{mL}$ ) only $18.75 \%$ were positive for S. aureus and $50 \%$ for S. agalactiae. The results show that the presence of these pathogens in the herd is an important risk factor for increased BMSCC (Table 1). The presence of S. aureus increased the risk for BMSCC above 700,000 cells $/ \mathrm{mL}$ of milk 14 times $(\mathrm{p}<0.001)$, while the presence of $S$. agalactiae increased this risk four times ( $\mathrm{p}=0.035)$.

The presence of $S$. aureus and/or $S$. agalactiae is strictly associated with the increased BMSCC in the herd, due to its contagious nature and for predominantly causing subclinical mastitis, which negatively impacts milk quality (Jayarao et al. 2004, Keefe 2012). According to Philpot \& Nickerson (2002), increased BMSCC is due to the increment of IMI, especially the subclinical mastitis that occurs when these pathogens are present in the herd.

The inflammatory process of mastitis triggers the release of proinflammatory cytokines that induce the passage of leucocytes from the blood to the interior of the gland, leading to increased individual SCC and consequent increase of BMSCC. The lesions in the mammary tissue decrease the efficiency 
Table 1. Sanitary handling variables associated with the values of image result for bulk milksomatic cell counts (BMSCC) $\geq 700,000$ cells $/ \mathrm{mL}$

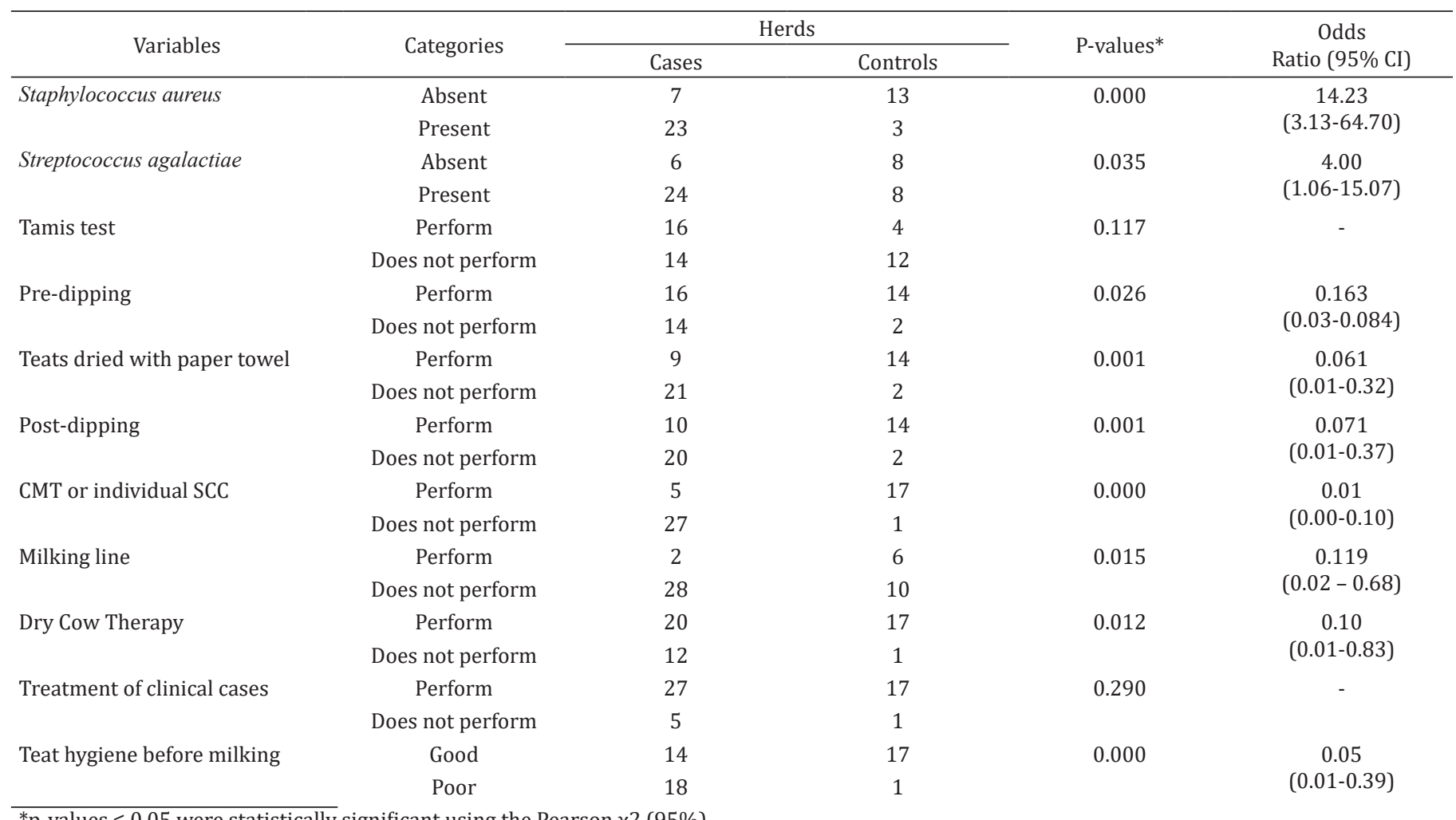

*p-values $\leq 0.05$ were statistically significant using the Pearson $\chi 2$ (95\%).

of the secretory cells, i.e., they produce and secret less milk (Brito et al. 2001).

Our results showed that the most of the studied variables were confirmed as risk factors of BMSCC above 700,000 cells $/ \mathrm{mL}$ of milk (Table 1). This can be observed for the variables pre-dipping $(\mathrm{OR}=0.163, \mathrm{p}=0.026)$, teats dried with disposable paper towel $(\mathrm{OR}=0.061, \mathrm{p}=0.001)$ and post-dipping $(\mathrm{OR}=0.071$, $\mathrm{p}=0.001$ ). The use of these practices reduced the risk for increased BMSCC, indicating that they are protective factors. The lack of pre-dipping, drying of teats with disposable paper towel and post-dipping increased the risk for BMSCC in 6.1, 16.4 and 14.08 respectively.

The variables treatment of cows with clinical mastitis, Tamis test and automated hygiene of milk machine were not correlated with the BMSCC scores, suggesting that they did not impact this parameter(Table 2). Indeed the equipment hygiene and sanitizing procedures have a more significant impact in the total bacterial count (TBC) compared to BMSCC; however, they may lead to new IMI and consequently increased BMSCC when these requisites are not fully met.

Souza et al. (2005) observed herd characteristics and handling practices associated to the increase of BMSCC in 175 milk herds located in the Zona da Mata in the Minas Gerais state, verifying that performing the Tamis test did not correlate with BMSCC, a result that is corroborated in our study. The same author also observed that the nonuse of milking line and lack of pre and post dipping were associated to increase of BMSCC, again corroborating with our results.
The mastitis risk factors were studied by Mendonça et al. (2016) in 186 herds with BMSCC above 400,000 cells/mL, also located Zona da Mata region in the Minas Gerais state. The results showed that the main risk factors for increased BMSCC in the herds were related to inadequate handling practices: nonuse of Tamis test; feed the cows while milking and lack of post dipping.

Our study showed that the variable use of Tamis test was not associated with BMSCC. This was an unexpected result. This test allows to identifying animals affected with clinical mastitis for immediate treatment and disposal of their milk, which usually present high SCC. Thus, we expected that the use of this test to be a protective factor against BMSCC. However, we observed that this test is usually performed inappropriately. Many times, positive animals do not receive any treatment and their milk, affected by clinical mastitis, is not always discarded which may justify the results found in our study.

In this study, in agreement to results of Allore et al. (1998) and Berry \& Hillerton (2002), the use of post dipping, treatment of dry cows and implantation of milking line were observed as protection factors for the increment of BMSCC. However, differently from the results obtained by these authors, the early treatment of mastitis clinical cases was not observed as a risk factor for high BMSCC. This may be due to the fact that almost all studied properties applied this procedure, both those with low and high BMSCC, but the frequency and method of use of this control measure, wich usually varies among herds, were not evaluated.

In the properties with mastitis monitoring through CMT, treatment of dry cow and milking line use, we observed 
Table 2. Sanitary handling variables associated with bulk milk somatic cell counts (BMSCC) $\geq 700,000 \mathrm{cells} / \mathrm{mL}$

\begin{tabular}{|c|c|c|c|c|c|}
\hline \multirow{2}{*}{ Variables } & \multirow{2}{*}{ Categories } & \multicolumn{2}{|c|}{ Herds } & \multirow{2}{*}{ P-values* } & \multirow{2}{*}{$\begin{array}{c}\text { Odds } \\
\text { Ratio }(95 \% \mathrm{CI})\end{array}$} \\
\hline & & Cases & Controls & & \\
\hline \multirow[t]{2}{*}{ Automated milking cleaning } & Yes & 18 & 6 & 0.217 & - \\
\hline & No & 12 & 10 & & \\
\hline \multirow[t]{2}{*}{ Pressure in the milking collectors } & Perform & 11 & 1 & 0.021 & $\begin{array}{c}8.90 \\
(1.05-76.04)\end{array}$ \\
\hline & Does not perform & 21 & 17 & & \\
\hline \multirow[t]{2}{*}{ Milking vacuum pressure } & Normal & 22 & 17 & 0.036 & $\begin{array}{c}0.13 \\
(0.02-1.11)\end{array}$ \\
\hline & Unregulated & 10 & 1 & & \\
\hline \multirow[t]{2}{*}{ Loss of vacuum during milking } & Yes & 9 & 1 & 0.055 & $\begin{array}{c}6.65 \\
(0.77-57.63)\end{array}$ \\
\hline & No & 23 & 17 & & \\
\hline \multirow{2}{*}{$\begin{array}{l}\text { Maintenance of milking machine and } \\
\text { bulk milk tank }\end{array}$} & Good & 0 & 16 & 0.000 & Undefined \\
\hline & Poor & 30 & 0 & & \\
\hline
\end{tabular}

protective effect $(\mathrm{p}<0.05)$, and the nonuse of these practices increased the risk of BMSCC above 700,000 cells/mL in 100, 10 and 8.4 times, respectively (Table 1 ).

Oliveira et al. (2012) studied the risk factors associated with bovine mastitis (SCC > 200,000 cells /mL) in 21 properties of the microregion of Garanhuns, Pernambuco state. The authors observed that the risk factors associated to the disease were the non-treatment of dry cows, non-drying of the teats with disposable paper towel and the nonuse of pre dipping; these results corroborate with ours.

Our results showed that, with exception of the Tamis test and the treatment of clinical cases, the deficiency or absence of mastitis control and prevention measures lead to increse of the BMSCC in the studied herds.

According to Lopes et al. (2011), increased BMSCC can lead to direct economic loss to the producer, since a large portion of the dairies adopts payment according to the milk quality, a fact that directly affects the mastitis economic impact. In another study, Lopes et al. (2012) verified that expenses with mastitis prevention represent a much lower cost compared to corrective measures and the production loss caused by increased BMSCC, which shows the advantages of investing in good milking handling practices that significantly contribute to the reduction of BMSCC, and consequently to reduction of the mastitis economic impact.

All the variables related to milking equipments were confirmed as risk factors for BMSCC above 700,000 (Table 2). The variable maintenance of the milking machine and bulk milk tank revealed complete association, i.e., all properties with any kind of failure in the maintenance or adjustments of the milking machine and/or milk bulk tank had BMSCC $\geq 700,000$. Those properties without these problems had BMSCC $\leq 200,000$ $(\mathrm{p} \leq 0.001)$, showing that these variables are highly associated to BMSCC. The variables inadequate pressure in the milking cluster and loss of vacuum during milking were also considered as risk factors. The presence of these variables in the properties led to increased risk of BMSCC $\geq 700,000$ cells/mL in 8.90 and 6.65 respectively (Table 2 ).

Coentrão et al. (2008) studied subclinical mastitis risk factors (SCC >200,000 cells/mL of milk) in 2,657 cows from 24 herds from Minas Gerais state from November 2005 to June 2006. They observed that the main subclinical mastitis risk factors were related to cracks and fissures in the rubber parts of the milking equipment, inadequate teat cups, lack of maintenance of the pulsers, lack of milkers' training and the nonuse of mastitis microbiological diagnosis. Many of the risk factors related to inadequate functioning and lack of maintenance of the milking machine pointed out by these researchers also were observed in our study.

Dysregulated or defective milking equipment, lack of staff training and not adopting the recommended procedures for control and prevention of mastitis were the risk factors detected by Brito et al. (2002) and Cavazos (2003) for increased SCC. These variables interact and affect the frequency of increase in the herd's BMSCC and, consequently, of mastitis presence.

As for the quantitative variables, we observed a positive correlation between BMSCC and the counts of $S$. aureus and $S$. agalactiae in the milk (Table 3 ), suggesting that the increase of these agents in the bulk milk tank would be associated to the their higher prevalence in the herd. However, according to Oliver et al. (2004b), the counts of these pathogens in the bulk milk tank are not directly associated to their prevalence in the herd.

Souza et al. (2009) evaluated the effect of mastitis pathogens on SCC in 3,987 samples of milk from 2,657 animals from 24 milking herds located in the states of Rio de Janeiro and Minas Gerais. In this study they verified that SCC presented an average of 264,000 cells/mL of milk samples without 
Table 3. Quantitative variables associated with bulk milk somatic cell counts (BMSCC) $\geq 700,000 \mathrm{cells} / \mathrm{mL}$

\begin{tabular}{|c|c|c|c|c|c|c|}
\hline \multirow{2}{*}{ Variables } & \multicolumn{3}{|c|}{ Controls $^{\mathrm{a}}$} & \multicolumn{3}{|c|}{ Cases $^{\mathrm{b}}$} \\
\hline & Mean & $Q_{1}-Q_{3}$ & Min.-Max. & Mean & $Q_{1}-Q_{3}$ & Min.-Max. \\
\hline BMSCC (cells $/ \mathrm{mL} \times 10^{3}$ ) & 162.25 & $130.25-190,79$ & $51-209$ & 934.00 & $786.96-1,118.21$ & $707-1,573$ \\
\hline Dialy milk production (L) & 224.50 & $139.50-323.00$ & $52-3673$ & 290.58 & $168.98-566.75$ & $59-1,736$ \\
\hline Count of Staphylococcus aureus (UFC/mL) & 0 & $0.00-0.00$ & $0-1400$ & 110.00 & $9.00-1,325.00$ & $0-83,000$ \\
\hline Count of Streptococcus agalactiae (UFC/mL) & 525 & $0.00-2,380.00$ & $0-3,800$ & 3,650 & $52.75-25,250.00$ & $0-16,6000$ \\
\hline
\end{tabular}

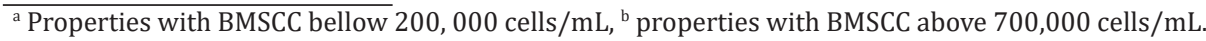

Table 4. Correlations between bulk milk somatic cell counts (BMSCC), dialy milk production, count of Staphylococcus aureus and count of Streptococcus agalactiae

\begin{tabular}{lcccc}
\hline \multicolumn{1}{c}{ Varibles } & BMSCC & Dialy milk production & Count of S. aureus & Count of S. agalactiae \\
\hline BMSCC & 1.000 & 0.194 & $0.400^{\mathrm{a}}$ & $0.320^{\mathrm{b}}$ \\
Dialy milk production & 0.194 & 1.000 & 0.110 & -0.075 \\
Count of $S$. aureus & $0.400^{\mathrm{b}}$ & 0.110 & 1.000 & $0.406^{\mathrm{a}}$ \\
Count of $S$. agalactiae & $0.320^{\mathrm{a}}$ & -0.075 & $0.406^{\mathrm{a}}$ & 1.000
\end{tabular}

${ }^{a}$ Spearman correlation with significant level of $0.01,{ }^{\mathrm{b}}$ correlation with significant level of 0.05 .

bacterial growth. When S. agalactiae was isolated, the SCC average was of $1,520,000$ cells $/ \mathrm{mL}$ of milk, with $50 \%$ of the samples presenting SCC $\geq 923,000$ cells $/ \mathrm{mL}$. The same authors also observed that the presence of $S$. aureus was responsible for the second highest increase of SCC, with an average of 966,000 cells $/ \mathrm{mL}$. These results corroborate with ours, showing that these pathogens have great impact on BMSCC when present in the herd.

The results for the correlation between daily milk production and count of $S$. aureus ( $\mathrm{p}=0.467)$, and between daily milk production and count of $S$. agalactiae $(\mathrm{p}=0.627)$ were not significant, showing that the farms daily production does not affect the numbers of these pathogens in the milk (Table 4). However, we observed moderate correlations between BMSCC and counts of $S$. aureus $(\mathrm{p}=0.06)$ and a positive correlation between BMSCC and counts of $S$. agalactiae $(\mathrm{p}=0.032)$. In concordance of our resultas, Cortinhas (2013) studied the correlation between SCC and the count of mastitis pathogens in herds from the state of São Paulo. This author found low correlation between the count of de S. aureus and BMSCC, and moderate positive correlation between the count of S. agalactiae and BMSCC ( $\mathrm{r}=0.49)$.

Botaro et al. (2013) evaluated the correlation between the numbers of CFU/mL of S. aureus and SCC in samples of milk from individual mammary quarts. The authors observed no dependent correlation between the variables $(p=0.1948)$, which is related to the intermittent elimination of the agent (Oliver et al. 2004b). This discordance with our results may be due to differences in the samples analyzed, since our study was performed with milk from bulk tanks. However, Sears et al. (1990) e Shoshani et al. (2000), even though using individual samples, pointed out the increased rate of elimination of $S$. aureus in the milk of animals chronically affected by S. aureus, concomitantly with increased SCC.

Djabri et al. (2002) observed that one single mammary quart infected with $S$. aureus and $S$. agalactiae resulted in 357,000 cells/mL and 857,000 cells/mL of milk, respectively, proving that the presence of these two pathogens is directly correlated with SCC and BMSCC. The presence of these microorganisms in milk, considered primary pathogens, was also related to the incremented SCC by Reis et al. (2011). The correlation between the counts of S. aureus and S. agalactiae with BMSCC suggests that this parameter may indicate the prevalence of these pathogens and the level of subclinical mastitis in the herd.

We also found a positive correlation between the counts of these pathogens (Table 4), showing that the increased count of one pathogen is associated to increased count of the other. This fact can be related to their contagious nature and similar epidemiological determinants.

Our results show that practices of prevention and control of mastitis related to the herd handling, maintenance of milking equipment and monitoring of mastitis are strictly correlated to the levels of BMSCC in the herd, justifying investments in these practices implementation, as shown by Lopes et al. (2011). These researchers reported that expenses with mastitis prevention, including culture and antibiogram, monitoring of BMSCC and individual SCC, pre and post dipping, vaccination against mastitis pathogens, treatment of dry cows and milking machine maintenance represent at most $10.8 \%$ of the economic impact associated with increased BMSCC in the herd. This highlights the economic return that will occur due to the implantation of these measures, which will significantly contribute to the reduction of BMSCC and improved milk quality.

Our results offer subsides for the elaboration of strategies to solve sanitary problems that influence BMSCC, improving the herds productivity, and not less important, the quality of the raw material, leading to higher profitability to producers and industry.

\section{CONCLUSIONS}

The presence and concentration of the pathogens Staphylococcus aureus and Streptococcus agalactiae are relevant risk factors for BMSCC $\geq 700,000$ cells $/ \mathrm{mL}$.

There are moderate correlations between BMSCC and $S$. aureus and S. agalactiae counts, and moderate correlation between the $S$. aureus and S. agalactiae counts. 
The nonuse of classical measures of control and prevention of mastitis related to the handling and milking hygiene, pre and post dipping, use of disposable paper towel to dry the teats, monitoring of the herd through CMT, implementation of milking line, dry cow therapy and lack of hygiene of the teats and udders were indicated as relevant risk factors for BMSCC $\geq 700,000$ cells $/ \mathrm{mL}$.

The variables related to milking equipments, pressure applied to the milking sets, dysregulated milking vacuum pressure during milking and maintenance failures of the milking machine and bulk milk tank were identified as risk factors for BMSCC $\geq 700,000$ cells $/ \mathrm{mL}$.

Conflict of interest statement - The authors have no competing interests.

\section{REFERENCES}

Allore H.G., Erb H.N., Schruben L.W. \& Oltenacu P.A. 1998. A simulation of strategies to lower bulk tank somatic cell count below 500,000 per milliliter. J. Dairy Sci. 81(3):694-702. <http://dx.doi.org/10.3168/jds. S0022-0302(98)75625-5><PMid:9565872>

Barbano D.M., Ma Y. \& Santos M.V. 2006. Influence of raw milk quality on fluid milk shelf life. J. Dairy Sci. 89(Suppl.1):15-19.<http://dx.doi.org/10.3168/ jds.S0022-0302(06)72360-8><PMid:16527874>

Berry E.A. \& Hillerton J.E. 2002. The effect of selective dry cow treatment on new intramammary infections. J. Dairy Sci. 85(1):112-121. <http:// dx.doi.org/10.3168/jds.S0022-0302(02)74059-9> <PMid:11860103>

Botaro B.G., Cortinhas C.S., Março L.V., Moreno J.F.G., Silva L.F.P., Benites N.R. \& Santos M.V. 2013. Detection \& enumeration of Staphylococcus aureus from bovine milk samples by real-time polymerase chain reaction. J. Dairy Sci. 96(11):6955-6964. <http://dx.doi.org/10.3168/jds.2013-6559> $<$ PMid:24054287>

Brasil 2002. Instrução Normativa 51, de 18 de setembro de 2002. Regulamento Técnico de Produção, Identidade e Qualidade do Leite Tipo A, tipo B, Tipo C e Cru Refrigerado, Diário Oficial da União, Seção 1, Ministério da Agricultura, Pecuária e Abastecimento, Brasília, DF, p.13.

Brasil 2011. Instrução Normativa 62, de 29 de dezembro de 2011. Dispõe sobre Regulamentos Técnicos de Produção, Identidade, Qualidade, Coleta e Transporte do Leite, Diário Oficial da União, Seção 1, Ministério da Agricultura, Pecuária e Abastecimento, Brasília, DF.

Brasil 2016. Instrução Normativa 07, de 3 de maio de 2016. Dispõe sobre Alterações nos Regulamentos Técnicos de Produção, Identidade, Qualidade, Coleta e Transporte do Leite, Diário Oficial da União, Seção 1, Ministério da Agricultura, Pecuária e Abastecimento, Brasília, DF.

Brito M.A.V.P., Brito J.R.F., Souza H.M. \& Vargas O.L. 1998. Avaliação da sensibilidade da cultura de leite do tanque para isolamento de agentes contagiosos da mastite bovina. Pesq. Vet. Bras. 18(1):39-44. <http://dx.doi. org/10.1590/S0100-736X1998000100007>

Brito M.A.V.P., Brito J.R.F., Ribeiro M.T. \& Veiga V.M.O. 1999. Padrão de infecçäo intramamária em rebanhos leiteiros: exame de todos os quartos mamários das vacas em lactaçäo. Arq. Bras. Med. Vet. 51(2):129-135. <http://dx.doi. org/10.1590/S0102-09351999000200001>

Brito M.A.V.P., Brito J.R.F., Silva M.A.S. \& Carmo R.A. 2001. Concentração mínima inibitória de dez antibióticos para amostras de Staphylococcus aureus isoladas de infecção intramamária bovina. Arq. Bras. Med. Vet. 53(5):531-537. <http://dx.doi.org/10.1590/S0102-09352001000500003>

Brito J.R.F., Brito M.A.V.P. \& Arcuri E.F. 2002. Como (Re)conhecer e Controlar a Mastite em Rebanhos Bovinos. Circular Técnica 70, Embrapa Gado de Leite, Juiz de Fora, MG, 8p.

Carvalho G.R. 2010. A Indústria de Laticínios no Brasil: passado, presente e futuro. Circular Técnica 102, Embrapa Gado de Leite, Juiz de Fora, 12p.
Cavazos G.F. 2003. Useful ideas and principles for the implementation of reinforcement programs to keep milkers motivated. Proceedings of the Annual Meeting of National Mastitis Council, Fort Worth, TX, p.23-37.

Coentrão C.M., Souza G.N., Brito J.R.F., Paiva e Brito M.A.V. \& Lilenbaum W. 2008. Fatores de risco para mastite subclínica em vacas leiteiras. Arq. Bras. Med. Vet. 60(2):283-288. <http://dx.doi.org/10.1590/S010209352008000200001>

Cortinhas C.S. 2013. Qualidade do leite cru e práticas de manejo em fazendas leiteiras. Doctoral Dissertation in Veterinary Medicine, Universidade de São Paulo, Pirassununga, SP. 127p. <http://dx.doi.org/10.11606/T.10.2013. tde-21082014-111709>

Costa G.M., Paiva L.V., Figueiredo H.C.P., Figueira A.R., Pereira U.P. \& Silva N. 2012. Population diversity of Staphylococcus aureus isolated from bovine mastitis in brazilian dairy herds. Res. Vet. Sci. 93(2):733-735. <http:// dx.doi.org/10.1016/j.rvsc.2011.09.014> <PMid:22035658>

Djabri B., Bareille N., Beaudeau F. \& Seegers H. 2002. Quarter milk somatic cell count in infected dairy cows: a meta-analysis. Vet. Res. 33(4):335-357. <http://dx.doi.org/10.1051/vetres:2002021><PMid:12199362>

Dong F., Hennessy D.A. \& Jensen H.H. 2012. Factors determining milk quality and implications for production structure under somatic cell count standard modification. J. Dairy Sci. 95(11):6421-6435. <http://dx.doi.org/10.3168/ jds.2012-5522><PMid:22981577>

FAEMG 2006. Diagnóstico da pecuária leiteira do estado de Minas Gerais em 2005: relatório de pesquisa. Federação de Agricultura do Estado de Minas Gerais, Belo Horizonte, MG. 156p.

Guerreiro P.K., Machado M.R.F., Braga G.C., Gasparino E. \& Franzener A.S.M. 2005. Qualidade microbiológica de leite em função de técnicas profiláticas no manejo de produção. Ciênc. Agrotec. 29(1):216-222. <http://dx.doi. org/10.1590/S1413-70542005000100027>

IBGE 2017. Estatística da Produção Pecuária 2017. Instituto Brasileiro de Geografia e Estatística, Brasília, DF, p.1-78.

Jayarao B.M., Pillai S.R., Sawant A.A., Wolfgang D.R. \& Hegde N.V. 2004. Guidelines for monitoring bulk tank milk somatic cell and bacterial counts. J. Dairy Sci. 87(10):3561-3573. <http://dx.doi.org/10.3168/jds.S00220302(04)73493-1><PMid:15377636>

Keefe G. 2012. Update on control of Staphylococcus aureus and Streptococcus agalactiae for management of mastitis. Vet. Clin. N. Am., Food Anim. Pract. 28(2):203-216. <PMid:22664203>

Lopes M.A., Demeu F.A., Abreu L.R. \& Franco Neto A. 2011. Influência da contagem de células somáticas sobre o impacto econômico da mastite em rebanhos bovinos leiteiros. Arqs Inst. Biológico, São Paulo, 78(4):493-499.

Lopes M.A., Demeu F.A. \& Franco Neto A. 2012. Avaliação do impacto econômico da mastite. Arqs Inst. Biológico, São Paulo. 79:477-483.

Machado P.F., Pereira A.R. \& Sarríes G.A. 2000. Composição do leite de tanques de rebanhos brasileiros distribuídos segundo sua contagem de células somáticas. Revta Bras. Zootec. 29(6):1883-1886. <http://dx.doi. org/10.1590/S1516-35982000000600038>

Mendonça J.F.M., Brito M.A.V.P., Mendonça L.C., Souza G.N., Lange C.C., Brito J.R.F. \& Monteiro D.L. 2016. Fatores de risco para mastite subclínica em rebanhos leiteiros localizados na região de Santos Dumont, estado de Minas Gerais, Brasil. Revta Educ. Cont. Med. Vet. Zootec. CRMV-SP. 14(3):71.

NMC 1996. Current concepts of bovine mastitis. National Mastitis Council, Madison, WI. 64p.

NMC 2000. Recommended mastitis control program. National Mastitis Council, Madison, WI. 78p.

Oliver S.P., González R.N., Hogan J.S., Jayarao B.M. \& Owens W.E. 2004a. Microbiological Procedures for the Diagnosis of Bovine Udder Infection and Determination of Milk Quality. 4th ed. National Mastitis Council, Verona, WI, 46p. 
Oliver S.P., Gillespie B.E., Headrick S.J., Moorehead H., Lunn P., Dowlen H.H., Johnson D.L., Lamar K.C., Chester S.T. \& Moseley W.M. 2004b. Efficacy of extended ceftiofur intramammary therapy for treatment of subclinical mastitis in lactating dairy cows. J. Dairy Sci. 87(8):2393-2400. <http:// dx.doi.org/10.3168/jds.S0022-0302(04)73361-5><PMid:15328260>.

Oliveira J.M.B., Vanderlei D.R., Moraes W.S., Brandespim D.F., Mota R.A., Oliveira A.A.F., Medeiros E.S. \& Pinheiro Júnior J.W. 2012. Fatores de risco associados à mastite bovina na microrregião Garanhuns, Pernambuco. Pesq. Vet. Bras. 32(5):391-395. <http://dx.doi.org/10.1590/S0100-736X2012000500005>

Omore A.O., McDermott J.J., Arimi S.M., Kyule M.N. \& Ouma D. 1996. A longitudinal study of milk somatic cell counts and bacterial culture from cows on smallholder dairy farms in Kiambu District, Kenya. Prev. Vet. Med. 29(1):77-89. <http://dx.doi.org/10.1016/S0167-5877(96)01054-9>

Philpot W.N. \& Nickerson S. 2002. Vencendo a Luta Contra a Mastite. Westfalia Landtechnik do Brasil Ltda., São Paulo. 189p.

Politis I. \& Ng-Kwai-Hang K.F. 1988. Effects of somatic cell count \& milk composition on cheese composition and cheese making efficiency. J. Dairy Sci. 71(7):1711-1719. <http://dx.doi.org/10.3168/jds.S00220302(88)79737-4>

Ranjan R., Swarup D., Patra \& Nandi R.C.D. 2006. Bovine protothecal mastitis: a review. CAB Revs. Perspectives Agricult. Vet. Sci. Nutr. Nat. Resources 1(17):1-7.

Rêgo M.A.V.2010. Case-control studies: a brief review. Gaz. Méd. 80(1):101-110.

Reis C.B.M., Barreiro J.R., Moreno J.F.G., Porcionato M.A.F. \& Santos M.V. 2011. Evaluation of somatic cell count thresholds to detect subclinical mastitis in gyr cows. J. Dairy Sci. 94(9):4406-4412. <http://dx.doi.org/10.3168/ jds.2010-3776><PMid:21854914>

Reyher K.K., Haine D., Dohoo I.R. \& Revie C.W. 2012. Examining the effect of intramammary infections with minor mastitis pathogens on the acquisition of new intramammary infections with major mastitis pathogens: a systematic review and meta-analysis. J. Dairy Sci. 95(11):6483-6502. <http://dx.doi. org/10.3168/jds.2012-5594><PMid:22981582>

Ribeiro M.G. 2008. Princípios terapêuticos na mastite em animais de produção e de companhia, p.759-771. In: Andrade S.F. (Ed), Manual de Terapêutica Veterinária. 3aㅡ ed. Roca, São Paulo.

Sears P.M., Smith B.S., English P.B., Herer P.S. \& Gonzalez R.N. 1990. Shedding pattern of Staphylococcus aureus from bovine intramammary infections. J. Dairy Sci. 73(10):2785-2789. <http://dx.doi.org/10.3168/jds.S00220302(90)78964-3><PMid:2283409>

Santos M.V. \& Fonseca L.F.L. 2007. Estratégias para Controle de Mastite e Melhoria da Qualidade do Leite. Manole, Barueri. 150p.

Shoshani E., Leitner G., Hanochi B., Saran A., Shpigel N.Y. \& Berman A. 2000. Mammary infection with staphylococcus aureus in cows: progress from inoculation to chronic infection and its detection. J. Dairy Res. 67(2):155-169. <http://dx.doi.org/10.1017/S002202990000412X> <PMid:10840670>

Souza G.N. 2005. Fatores de risco para mastite bovina. Doctoral Dissertation in Veterinary Medicine, Universidade Federal de Minas Gerais, Belo Horizonte, MG. 87p.

Souza G.N., Brito J.R.F., Moreira E.C., Brito M.A.V.P. \& Bastos R.R. 2005 Fatores de risco associados à alta contagem de células somáticas do leite do tanque em rebanhos leiteiros da Zona Da Mata de Minas Gerais. Arq. Bras. Med. Vet. 57(Suppl.2):251-260.<http://dx.doi.org/10.1590/S0102$09352005000800018>$

Souza G.N., Brito J.R.F., Moreira E.C., Brito M.A.V.P. \& Silva M.V.G.B. 2009 Variação da contagem de células somáticas em vacas leiteiras de acordo com patógenos da mastite. Arq. Bras. Med. Vet. 61(5):1015-1020.<http:// dx.doi.org/10.1590/S0102-09352009000500001>

Vilela P.S. \& Nogueira A.E.C. 2010. Perfil do Produtor de Leite nas Mesorregiões da Zona da Mata e Campo das Vertentes de Minas Gerais. Pólo de Excelência do Leite e Derivados, Secretaria de Ciência, Tecnologia e Ensino Superior, Governo do Estado de Minas Gerais, Belo Horizonte, MG. 119p. 